\title{
Нуллификация в башкирских пословицах
}

\section{Б. Т. Ганеев}

Башкирский государственный педагогический университет им. М. Акмуллы

Россия, Республика Башкортостан, 450008 г. Уфа, улица Октябрьской

революции, 3 а.

Email: bulgan2000@yandex.ru

В статье рассматриваются проявления нуллификации, т.е. языковых элементов, выражающих отсутствие (ничто, небытие, пустоту, отрицание) материальных или идеальных объектов. Нуллификация различается по степени присутствия ничто: полная и частичная нуллификация, самонуллификация, внешняя нуллификация (нехватка, урон, ранение, гибель, уничтожение формы, забывание). Материалом исследования являются башкирские пословицы, где доля нуллификации составляет $21 \%$, которые анализируются в лексико-семантическом и грамматическом планах. Делается вывод о превалировании грамматической нуллификации, прежде всего в виде отрицания.

Ключевые слова: нуллификация, пословица, башкирский, ничто, отрицание.

Пословицы представляют собой сжатый комплекс всех актуальных высказываний, своего рода экстракт речи, благодарный материал для исследователя, который боится утонуть в необъятном океане языка. Преимущества анализа нуллификации на примере пословиц состоит также в том, что с конечным множеством, которое представляют собой устойчивые выражения, легче проводить статистические исследования, например, выявлять частотность использования тех или иных языковых единиц.

Башкирские пословицы и поговорки изучали многие исследователи, начиная с М. Г. Куватова до Ф. А. Надршиной.

В данной работе башкирские пословицы рассматриваются в свете понятия «ничто». Данным понятием охватываются все случаи отсутствия конкретного или абстрактного концепта, который может быть потенциально выражен языком или уже выражался в речи. Это отсутствие предлагается обозначить термином «нуллификация», которым описываются проявления «ничто», «небытия», «пустоты» в языке и речи. Эти проявления разнообразны [2].

Мы выделяем три вида небытия: несуществующее для нас, временно не существующее для нас, существующее для нас, но не существующее для других.

Мы находим ничто в космогонии (возникновение мира из ничто), в природе (вакуум), в науке (ноль), в философии (небытие), в обществе (плацебо) и т.д. 
Нуллификация различается по степени присутствия ничто.

Кроме полной и частичной нуллификации можно выделить самонуллификацию (внутреннюю нуллификацию, т.е самоуничтожение, гибель) и внешнюю нуллификацию (потерю внешнего атрибута, например, вещи или нехватку, например, недостаток пищи). Сюда же относятся глоссемы, обозначающие разрушение, урон, ранение, убийство, т.е. частичная (ранил) или полная (убил) нуллификация. Нуллификация может рассматриваться как уничтожение формы (поел, выпил и т.д.). Она приводит к видимому исчезновению материи, или его переходу в другое состояние, т.е. изменению формы. Сюда же можно отнести и ментальную нуллификацию: забывание или безальтернативность как нуллификацию выбора. Нуллификация может быть конкретной (здесь нет никого) или обобщенной: Никого на свете нет. Никто меня не понимает.

Речевая неполнота может выражаться через грамматическое и семантическое эллиптирование и умолчание. Но от них следует отличать намеренные семантические пропуски, которые были всесторонне исследованы в работах Т. Г. Миролюбовой [3]. Эти пропуски могут быть окказиональными и узуальными. Имплицитность в речи столь же важна, как эксплицитность.

Графическое ничто. Сюда прежде всего относятся знаки, не имеющие звукового содержания (например «немые» буквы в английском и французском), и другие подобные явления, например: Отсутствие огласовок в арабском и еврейском языках, а также отсутствие диакритических знаков у русской буквы ё (=е).

Лексическое ничто. Слово, фраза, предложение (т.е. глоссема) сами по себе вне контекста имеют формально нулевое значение (нуллификация формы). Такая нуллификация характерена для идиом, где все эсксплицитные составляющие нуллифицируются, поскольку основной смысл узуально имплицитен. К лексическому ничто можно отнести случаи полисемии, энантиосемии, омонимии, оксюмороны и т.д., где настоящее значение проявляется в высказывании.

Грамматическое ничто. Нулевые элементы (нулевые морфемы, парадоксальные функции единственного и множественного числа и т.д.) широко используются в грамматике Как ни странно, избыточность в языке - это тоже ноль, поскольку это пустая материя, в которой нет необходимости. Например, имеются также пустые суффиксы (табуретка, тарелка).

В башкирском языке (и для ряда других языков) характерны грамматические формы и лексемы для «отсутствующих очевидцев», например, две формы прошедщего времени: 1) прошедшее определенное: килде 'он пришел'; 2) прошедшее неопределенное: килгән 'он, оказывается, пришел'. В первом случае говорящий сам видел, во втором сам не видел, говорит, то, чего, возможно и не было. 
Отрицание - это самое распространенное грамматическое ничто, своего рода универсалия. В исследованном материале эксплицитное отрицание превалирует.

Отдельные слова - существительные, прилагательные, глаголы и другие части речи могут обладать внутренним отрицанием, семантическим и грамматическим. Примеры: «потеря», само слово «отрицание» и т.д.

Рассмотрим некоторые виды нуллификации в башкирских пословицах.

Лексико-семантическая нуллификация:

Аз̧ак - тутлы каз̧ак. Потом - ржавый гвоздь (в смысле: Потом - суп с котом). Налицо - материальный урон.

Ай күрз̧е, кояш алды. Был, да сплыл. (Материальная потеря)

Юғалған бысактың һабы алтын. Пропавший нож всегда позолоченный.

Асыу башы - йүләрлек, азағы - үкенеп ұләрлек.

Сердитый умрет - никто его не уймет. (Физическая смерть)

Батыр ұлеме бисәнән. Переплыл море, да в луже утонул.

Бурыслы ұлмас, әжәлле үлер. От долгов никто еще не удавился.

Атын урлаткас, hарайын бикләгән. (Визуальная потеря вещи)

Целы сани, а лошади пропали.

Әрһез̧лек - үз̧ең өсөн, бас̧алкылык - кеше өсөн.

На людях скромен, а дома темен.

Шығырлаған ағас кырк йыл ултыра. Битая посуда два века живет.

Параллелизм в семантической нуллификации:

ғүмере уз̧ған, күне туз̧ған. Его песенка спета.

Динамичная нуллификация:

Елдән килгән - силгә киткән. С ветру пришло, на ветер и пошло.

Двойная нуллификация:

Ашаған белмәй, тураған белә.

Не про то говорят, что съели, а про то, куда краюху дели.

Двойное отрицание:

Ауырымасุ тән булмасุ. Без болезни и здоровью не быть.

Парадоксальность как проявление небытия:

Акһак ултырмас,, hакау тик тормас̆. Немой не умолкнет, хромой не сядет. 
Аз̧наһына биш йома. Семь пятниц на неделе.

Ағыу менән дарыу бер заттан. Лекарство - тот же яд.

Ашыкhаң да, кабаланма. Поспешай не торопясь.

Отрицание в существительном:

Aкылhыз акырып алдырыр. Дураки горлом берут.

Ыитанһыз̧ билгә - кайыш бау. Без порток, а в шляпе.

Отрицательное слово:

«Юж»ка мин дә тук. На нет и мы сыты.

Южтан коз̧ағый. На безрыбье и рак рыба.

Двойная конструкция с отрицанием:

Юк тип көйөнмә, бар тип $\underline{\text { hөйөнмд. }}$

Не радуйся, нашедши, не плачь, потерявши.

Южтың башы ауыртмай. У «нет» голова не болит

Отрицание в параллельной конструкции

Ас̧ыл һөйәк зуур булмас, кайз̧а барһа - хур булмас̆. Мал золотник, да дорог.

Примеры сложной параллельной конструкции:

Абынмас аяк булмас, ярылмас таяк булмас.

И на доброго коня спотычка живет.

Бар яраштыра, юк талаштыра.

Нужда горюет, нужда воюет.

Шатлык күрһәң, шашма: каза күрһәң, азашма.

Когда радость - не ликуй, при беде - не паникуй.

Пример изящной лексико-грамматической игры:

Южтың аты юж. На нет и суда нет.

Повелительное наклонение

Ашаған табағыңза төкөрмд.

Не плюй в колодец, пригодится воды напиться.

Сложная семантико-грамматическая нуллификация

Әжәл hайлап килмәй. Смерть не разбирает чина.

Ашап туймағанды ялап туймасһынц.

Ложкой не наелся, языком не налижешься. 
Абайламай һөйләгән - ауырымай ұлгән.

Лишнее говорить - себе вредить.

Айhыз̆ атты, йылhыз̆ катынды мактама.

Коня хвали через месяц, а жену - через год.

Простая грамматическая нуллификация:

Без̧ капсыкта ятмай. Шила в мешке не утаишь.

Этлеккә тәһәрәт кәрәкмәй. Для брани ума не надо.

Аз̧ыклы ат арымас̆. Не лошадь, а корм везет.

Ай булмаһа, йондоз бар. Солнца нет, так и месяц светит.

Айыузан курккан урманға бармаған. Волков бояться, в лес не ходить.

Алйот юлдаш булмас, ишәк моңдаш булмас.

Дурак не спутник, осел не советчик.

Алма ағасынан алыс төшмәй. Яблоко от яблони далеко не падает.

Ас хәлен тук белмай. Сытый голодного не разумеет.

Ас̧тыртын эт өрмәй тешләй. Молчун-собака исподтишка хватает.

Боландың үз̧ мөгөз̧ө үз̧енә ауыр түгел. Своя ноша не тянет.

«Дыр», «зыыр»ға кош та кунмай. Если бы, да кабы, во рту бы росли бобы.

Заман бозок тұгел, әзам бозок. Не годы уроды, а люди.

Антонимия:

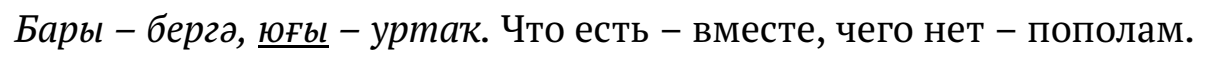

Суффиксальная антонимия:

Балалы өй - баз̧ар, балаһыз̧өй - маз̧ар.

Дом без детей - могила, дом с детьми - базар.

Балаһыз бер илай, балалы ун илай.

Без детей горе, а с ними вдвое.

Белмәйем - бер

Незнайка дома сидит, а знайку в суд ведут.

Данный анализ основан на исследовании корпуса из 1000 пословиц [6], где пословицы с нуллификацией составляют $21 \%$, две трети из которых представляют чисто грамматическую нуллификацию. Анализ другого собрания из 606 пословиц [4] выявил 35\% пословиц с нуллификацией.

Настоящая статья представляет собой первый очерк по исследованию нуллификации в башкирском языке и литературе, за которой последуют другие работы. 


\section{Литература}

1. Башкирское народное творчество. - т.7: Пословицы, поговорки. Приметы. Загадки. - Уфа: Башкирское издательство «КИТАП», 1993.

2. Ганеев Б. Т. Язык и ничто. - Уфа: Издательство БГПУ им. М. Акмуллы, 2018.

3. Миролюбова Т. Г. Намеренные смысловые пропуски в рамках микро- и макротекста. Ленинград, 1986.

4. Надршина Ф.А. Башкирско-англо-русский словарь адекватных пословиц и поговорок. Уфа: Китап, 2002. - 160 с. (в соавт.).

5. Надршина Ф. А. Русско-башкирский словарь пословиц-эквивалентов - Уфа: Изд-во «Китап» им. З. Биишевой, 2008. 196с

6. https://vk.com/topic-76766066_32307549

\section{Nullification in the Bashkir proverbs}

\section{B. T. Ganeev}

Bashkir State Pedagogical University named after M. Akmulla

3a Oktyabrskoi Revolutsii Street, 450008 Ufa, Republic of Bashkortostan, Russia.

Email:bulgan2000@yandex.ru

The article treats the manifestations of nullification, i.e. language units which express the absence (nothingness, non-being, emptiness, negation) of material and ideal objects. Nullification may be different according to the degree of the presence of nothingness: complete and partial nullification, self-nullification, outer nullification (lack, loss, wound, death, annihilation of the form, forgetting). As the material of the research were taken Bashkir proverbs the percentage of nullification in which constituted $21 \%$. They are analyzed in the semantic, lexical and grammatical aspects. The conclusion is made that it is the grammatical nullification that prevails, first of all in the form of negation.

Keywords: nullification, proverb, Bashkir, nothingness, negation. 